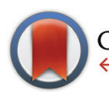

CrossMark \&lick for updates

Cite this: Dalton Trans., 2015, 44, 20514

Received 30th July 2015

Accepted 30th October 2015

DOI: $10.1039 / \mathrm{c} 5 \mathrm{dt} 02931 \mathrm{~g}$

www.rsc.org/dalton

\title{
Activation of molecular oxygen by a molybdenum complex for catalytic oxidation $\uparrow$
}

\author{
Antoine Dupé, ta $^{\mathrm{a}}$ Martina E. Judmaier, + $^{\mathrm{a}}$ Ferdinand Belaj, ${ }^{\mathrm{a}}$ Klaus Zangger $^{\mathrm{b}}$ and \\ Nadia C. Mösch-Zanetti*a
}

\begin{abstract}
A sterically demanding molybdenum(vi) dioxo complex was found to catalytically activate molecular oxygen and to transfer its oxygen atoms to phosphines. Intermediate peroxo as well as reduced monooxo complexes were isolated and fully characterized. Monomeric Mo(Iv) monooxo species proved to be of an unusual nature with the coordinated phosphine trans to the oxo group. The reduced molybdenum centers can activate $\mathrm{O}_{2}$ to form a stable Mo(vi) oxo-peroxo complex unambiguously characterized by single crystal $\mathrm{X}$-ray diffraction analysis. NMR experiments demonstrate that both oxygen atoms of the peroxo unit are transferred to an accepting substrate, generating the Mo(Iv) intermediate and restarting the catalytic cycle.
\end{abstract}

\section{Introduction}

High-valent molybdenum-oxo complexes are of considerable interest as catalysts for oxidation reactions. ${ }^{1,2}$ In nature, molybdenum oxotransferases are a broad class of enzymes that transfer an oxygen atom to or from a substrate, using mainly water as a source of oxygen. ${ }^{3}$ The active site of these enzymes consists of a molybdenum(vi) center substituted by at least one oxo group and one or two molybdopterin ligands. ${ }^{4}$ In order to mimic the activity of such enzymes, a wide range of model compounds containing a high valent $\left[\mathrm{MoO}_{2}\right]^{2+}$ core have been prepared. ${ }^{5}$ While oxygen atom transfer (OAT) capability of such complexes can be investigated using phosphines or sulfides as oxygen accepting substrates, they are also commonly used as catalysts for alkene epoxidation reactions and have thus found wide applications in industry. ${ }^{6}$ In the most efficient systems, tert-butyl hydroperoxide or hydrogen peroxide solutions are used as oxidant. ${ }^{1,7}$ However, following the principles of sustainable chemistry, the use of molecular oxygen as oxidant would be highly desirable; it is abundant, cheap, readily available and ideally does not lead to the formation of sideproducts. ${ }^{8}$ Despite these advantages, controlling the reactivity of dioxygen with transition metal centers is a challenge.

\footnotetext{
${ }^{a}$ Institute of Chemistry, University of Graz, Schubertstrasse 1, 8010 Graz, Austria. E-mail: nadia.moesch@uni-graz.at

${ }^{b}$ Institute of Chemistry, University of Graz, Heinrichstraße 28/II, 8010 Graz, Austria $\dagger$ Electronic supplementary information (ESI) available: Experimental procedures, X-ray crystallographic data, characterization data. CCDC 1413968 for 1 and 1413969 for 4. For ESI and crystallographic data in CIF or other electronic format see DOI: $10.1039 / \mathrm{c} 5 \mathrm{dt} 02931 \mathrm{~g}$

$\$$ These authors contributed equally to this work.
}

Although many iron, manganese and copper complexes are known to react with dioxygen, ${ }^{9}$ only rare examples of molecular oxygen activation by molybdenum have been previously reported, ${ }^{10,11}$ including one by our group, ${ }^{12}$ and the reactivity of these oxo-peroxo molybdenum is limited. Few homogeneously molybdenum catalyzed oxidations employing molecular oxygen were reported. A bimetallic molybdenum/copper catalyst was disclosed by Osborn and coworkers for the oxidation of alcohols. ${ }^{13}$ It represents a "Wacker-type reaction" where the alcohol is oxidized by molybdenum but reoxidation is mediated by the copper co-catalyst and not by molecular oxygen directly. Selected reports can be found in literature where $\mathrm{O}_{2}$ was used in Mo catalyzed oxidation chemistry ${ }^{14}$ but high catalyst loadings were needed and/or it remains unclear whether autooxidation is occurring.

In the course of our ongoing research on high-valent molybdenum-oxo complexes bearing Schiff-base ligands and their reactivity in OAT reactions, ${ }^{15-17}$ we report herein the synthesis and characterization of a new molybdenum(vi) dioxo complex which can be reduced and subsequently activate dioxygen to form a new molybdenum(vi) oxo-peroxo complex. This activation proceeds via the formation of a five-coordinated molybdenum(Iv) mono-oxo complex or a highly unusual trans$\left[\mathrm{MoO}(\mathrm{PMe})_{3}\right]^{2+}$ intermediate which was characterized by NMR spectroscopy and elemental analysis. Furthermore, we demonstrate that the molybdenum(vI) oxo-peroxo complex is also active in OAT reaction and able to transfer both oxygen atoms of the peroxo moiety to an accepting substrate. Benchmark oxidation of tertiary phosphine ${ }^{18}$ confirms the catalytic activity of the complexes. This reactivity is a new step toward the use of oxygen as oxidant in molybdenum-catalyzed oxidation reactions. 


\section{Results and discussion}

The molybdenum-dioxo complex $\left[\mathrm{MoO}_{2} \mathrm{~L}_{2}\right] \mathbf{1}$ was synthesized by addition of a solution of the ligand 2,4-di-tert-butyl-6-((tertbutylimino)methyl)phenol (HL) ${ }^{19}$ in toluene to a solution of 1 equiv. of $\left[\mathrm{MoO}_{2} \mathrm{Cl}_{2}\right]$ in toluene in presence of an excess trimethylamine (Scheme 1). After stirring for $15 \mathrm{~h}$, filtration and washing with cold pentane, $\mathbf{1}$ was obtained as a orange solid in good yield (64\%). The ${ }^{1} \mathrm{H}$ NMR spectrum reveals the formation of a single, symmetric isomer as only one set of resonances for both coordinated ligands is observed. The IR spectrum of 1 exhibits two strong $\nu_{\mathrm{Mo}=\mathrm{O}}$ bands at 885 and $912 \mathrm{~cm}^{-1}$ for both the symmetric and asymmetric stretching mode of the cis-[ $\left[\mathrm{MoO}_{2}\right]^{2+}$ fragment, in good accordance with the literature. ${ }^{16,20}$ Mass spectrometry as well as elemental analysis confirmed the formation of complex 1 as $\left[\mathrm{MoO}_{2} \mathrm{~L}_{2}\right]$.

This structure was confirmed by single crystal X-ray diffraction analysis. Suitable crystals were obtained from concentrated solution of $\mathbf{1}$ in toluene (Fig. 1). Crystal data and

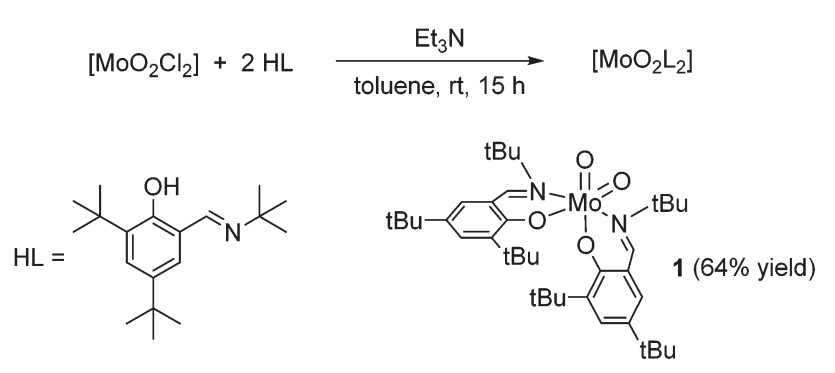

Scheme 1 Synthesis of Mo-dioxo complex 1.

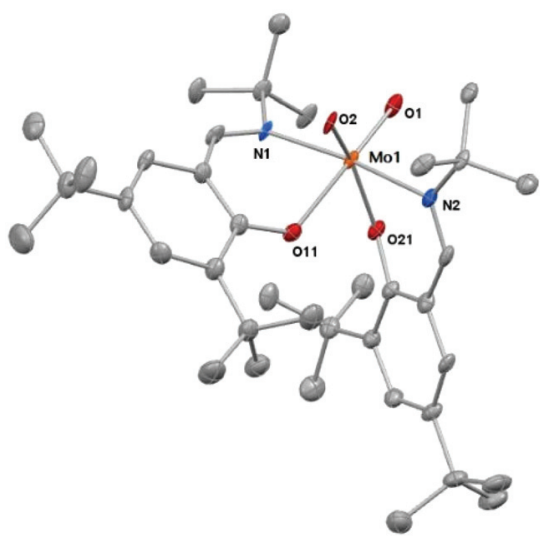

Fig. 1 Molecular structure of complex 1. Thermal ellipsoids have been drawn at $50 \%$ probability level. Hydrogen atoms are omitted for clarity. Selected bonds lengths ( $(\AA)$ and angles $\left(^{\circ}\right)$ : Mo(1)-O(2) 1.709(3); Mo(1)$\mathrm{O}(1)$ 1.720(3); $\mathrm{Mo}(1)-\mathrm{O}(21)$ 2.037(3); $\mathrm{Mo}(1)-\mathrm{O}(11)$ 2.105(3); $\mathrm{Mo}(1)-\mathrm{N}(1)$ 2.187(3); $\mathrm{Mo}(1)-\mathrm{N}(2)$ 2.228(4); O(11)-C(11) 1.309(5); $\mathrm{C}(1)-\mathrm{N}(1)$ 1.290(6); $\mathrm{N}(1)-\mathrm{C}(10)$ 1.518(5); $\mathrm{O}(21)-\mathrm{C}(21) 1.345(5) ; \mathrm{C}(2)-\mathrm{N}(2) 1.311(5) ; \mathrm{N}(2)-\mathrm{C}(20)$ 1.528(6); $\mathrm{N}(1)-\mathrm{Mo}(1)-\mathrm{N}(2) \quad 171.91(13) ; \quad \mathrm{O}(1)-\mathrm{Mo}(1)-\mathrm{O}(11) \quad 165.89(13) ;$ $\mathrm{O}(2)-\mathrm{Mo}(1)-\mathrm{O}(21)$ 159.04(13); $\mathrm{C}(11)-\mathrm{O}(11)-\mathrm{Mo}(1)$ 124.1(3); $\mathrm{C}(1)-\mathrm{N}(1)-$ $\mathrm{C}(10)$ 116.0(3); $\mathrm{C}(1)-\mathrm{N}(1)-\mathrm{Mo}(1)$ 116.9(3); $\mathrm{C}(10)-\mathrm{N}(1)-\mathrm{Mo}(1)$ 124.8(3); $\mathrm{C}(21)-\mathrm{O}(21)-\mathrm{Mo}(1)$ 131.2(3); $\mathrm{C}(2)-\mathrm{N}(2)-\mathrm{C}(20)$ 116.0(3); $\mathrm{C}(2)-\mathrm{N}(2)-\mathrm{Mo}(1)$ 121.8(3); C(20)-N(2)-Mo(1) 121.7(3).

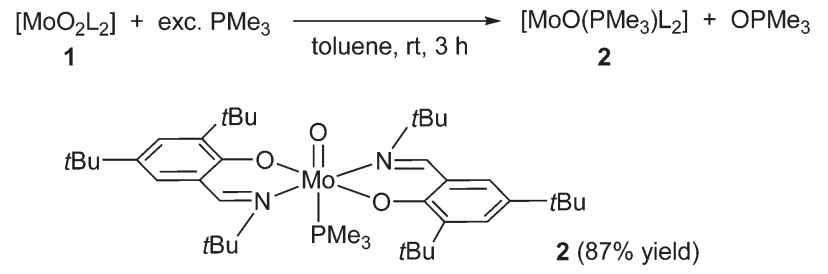

Scheme 2 Synthesis of molybdenum(Iv) complex 2.

structure refinements are presented in the Experimental section. Complex 1 exhibits a six-coordinate metal center in a distorted octahedral geometry.

Reactivity of the dioxo complex 1 in oxygen atom transfer (OAT) reactions was studied using trimethylphosphine and triphenylphosphine as oxygen acceptor substrates, allowing easy monitoring by ${ }^{31} \mathrm{P}$ NMR spectroscopy. Complex 1 was first reacted with an excess (4-5 equiv.) trimethylphosphine in toluene under inert conditions (Scheme 2).

The reaction was indicated by a quick change of color from deep orange to crimson and ${ }^{31} \mathrm{P}$ NMR measurements reveal the formation of $\mathrm{OPMe}_{3}$ and further reduced molybdenum(Iv) complex 2. After evaporation of the solvent and excess $\mathrm{PMe}_{3}$ then re-dissolution of the crude material in cold heptane, $\mathrm{OPMe}_{3}$ is removed via subsequent filtration over a pad of Celite. The pure reduced complex 2 was isolated as a highly sensitive to moisture and air, crimson solid in excellent yield (87\%). Interestingly, ${ }^{1} \mathrm{H}$ and ${ }^{13} \mathrm{C}$ NMR spectra revealed the formation of a symmetric compound as only one set of resonances for both coordinate ligands is observed (Table 1). Characteristic signals in the ${ }^{1} \mathrm{H}$ NMR spectrum in benzene- $\mathrm{d}_{6}$ are given at $8.33 \mathrm{ppm}$ (imine proton), 7.42 and $7.19 \mathrm{ppm}$ (aromatic protons). The ${ }^{31} \mathrm{P}$ NMR spectrum of a concentrated solution of 2 in benzene- $\mathrm{d}_{6}$ points to the existence of a single Mo$\mathrm{PMe}_{3}$ species (-9.47 ppm) further evidenced by the occurrence of a doublet at $0.91 \mathrm{ppm}$ with the integration of nine protons in the ${ }^{1} \mathrm{H}$ NMR spectrum.

The symmetric coordination in complex 2 has not been described in the literature up to now. In such type of OAT reactions, either the formation of a dimeric $\mathrm{Mo}(\mathrm{v})-\mathrm{O}-\mathrm{Mo}(\mathrm{v})$ species is observed, or the free coordination site is captured by a phosphine in cis position to the $[\mathrm{MoO}]^{2+}$ metal core, forming complexes of the type $\left[\mathrm{MoO}\left(\mathrm{PR}_{3}\right) \mathrm{L}_{2}\right]^{12,15,21}$ or $\left[\mathrm{MoO}\left(\mathrm{OPR}_{3}\right) \mathrm{L}_{2}\right] .^{22}$ Such complexes render the geometry around the metal center non-symmetric and therefore lead to two sets of resonances

Table $1{ }^{1} \mathrm{H}$ NMR characteristic signals shifts in ppm for complexes 1, 2, 3 and 4 in benzene- $d_{6}$

\begin{tabular}{llll}
\hline Compd. & $\mathrm{Ar}-\mathrm{CHN}$ & $\mathrm{Ar}-H$ & $\mathrm{Ar}-H$ \\
\hline $\mathbf{1}$ & 8.33 & 7.66 & 7.15 \\
$\mathbf{2}$ & 8.32 & 7.40 & 7.16 \\
$\mathbf{3}$ & 8.21 & 7.47 & 7.24 \\
$\mathbf{4}$ & $8.63,8.55$ & $7.60,7.49$ & $7.19,7.19$
\end{tabular}


for both coordinate ligands in NMR analysis. Our results point to the symmetric coordination of the $\mathrm{PMe}_{3}$ molecule in trans position to the $\mathrm{Mo}=\mathrm{O}$ moiety. Although an equilibrium between a trans and cis species is in principle feasible, this is very unlikely as we observe narrow peaks in NMR spectroscopy. Furthermore, low temperature ${ }^{31} \mathrm{P}$ NMR spectroscopy in toluene- $\mathrm{d}_{8}$ at $-30{ }^{\circ} \mathrm{C}$ shows only one signal (see ESI $\dagger$ ). This unusual arrangement is presumably caused by the high steric demand of the ligand. Two isomers are conceivable with the phosphine and the oxo groups trans to each other, namely the trans-N,N isomer depicted in Scheme 2 and the trans-N,O isomer, but the latter seems sterically too congested to exist.

ESI-MS measurements and elemental analysis corroborates the formation of a monomeric $\left[\mathrm{MoO}\left(\mathrm{PMe}_{3}\right) \mathrm{L}_{2}\right]$ complex. Information about the molecular size of the complex were obtained from 2D DOSY diffusion measurements on a sample containing complex 2 and free ligand in benzene- $\mathrm{d}_{6}$. For the free ligand (HL), a diffusion coefficient $D=-8.805\left(\log \left(\mathrm{m}^{2} \mathrm{~s}^{-1}\right)\right)$ corresponding to $1.57 \times 10^{-9} \mathrm{~m}^{2} \mathrm{~s}^{-1}$ was found, while complex 2 diffuses with a $D=-8.878\left(\log \left(\mathrm{m}^{2} \mathrm{~s}^{-1}\right)\right)$ corresponding to $1.32 \times 10^{-9} \mathrm{~m}^{2} \mathrm{~s}^{-1}$. Based on the Stokes-Einstein equation, the relative hydrodynamic radii of two components are related to the diffusion coefficients by $D_{1} / D_{2}=r_{2} / r_{1}$. Therefore, the experimental diffusions coefficients of complex 2 and free ligand correspond to relative hydrodynamic radii of $1.18: 1$. Such an increase of $18 \%$ of the diameter of the complex relative to $\mathrm{HL}$ can only be explained by a monomer. In addition, the DOSY analysis of a sample containing the dioxo complex $\mathbf{1}$ and the reduced complex 2 showed similar diffusion for both complexes (see ESI $\dagger$ ).

The OAT reaction of complex 1 with 2 equiv. $\mathrm{PPh}_{3}$ in benzene- $\mathrm{d}_{6}$ at room temperature as well results in a color change from deep orange to purple. After $5 \mathrm{~h}$ under stirring, an NMR sample was taken. ${ }^{1} \mathrm{H}$ and ${ }^{13} \mathrm{C}$ NMR spectra exhibited again one set of resonances for both coordinate ligands, indicating formation of a new symmetric compound $\left[\mathrm{MoOL}_{2}\right] 3$. Characteristic signals in ${ }^{1} \mathrm{H}$ NMR in benzene- $\mathrm{d}_{6}$ (Table 1) are given at $8.21 \mathrm{ppm}$ (imine proton), 7.47 and $7.24 \mathrm{ppm}$ (aromatic protons). ${ }^{31} \mathrm{P}$ NMR confirmed formation of $\mathrm{OPPh}_{3}$ (signal at $24.78 \mathrm{ppm}$ ) but showed that the other equivalent of $\mathrm{PPh}_{3}$ does not coordinate the molybdenum center and thus remains free (signal at $5.41 \mathrm{ppm}$ ). Evaporation of the solvent led to a highly air sensitive purple powder which contains 3, $\mathrm{OPPh}_{3}$ and $\mathrm{PPh}_{3}$. Removal of $\mathrm{OPPh}_{3}$ was performed by filtration of a heptane solution of the mixture over dry Celite, which however did not remove residual $\mathrm{PPh}_{3}$. Thus, sublimation of residual $\mathrm{PPh}_{3}$ at $100{ }^{\circ} \mathrm{C}$ was attempted to isolate 3 , but only lead to decomposition of the complex. Nevertheless, its sensitivity towards air as well as ${ }^{1} \mathrm{H}$ and ${ }^{31} \mathrm{P}$ NMR spectroscopy lead us to believe that the monooxo $\left[\mathrm{MoOL}_{2}\right]$ complex 3 is formed in situ rather than a Mo(v) dimer or a Mo(rv) phosphino species. The monomeric structure of 3 was confirmed by DOSY analysis, with a diffusion coefficient similar to that obtained for complex 2 .

Although complexes with the $\left[\mathrm{MoO}\left(\mathrm{O}_{2}\right)\right]^{2+}$ or $\left[\mathrm{MoO}\left(\mathrm{O}_{2}\right)_{2}\right]^{2+}$ cores are relatively abundant in the literature, as complexes thereof are available from the reaction of $\left[\mathrm{MoO}_{3}\right]$ and the appropriate ligand in aqueous $\mathrm{H}_{2} \mathrm{O}_{2},{ }^{23}$ the activation of molecular oxygen by molybdenum compounds is scarce in the literature. As previously described by our group, re-oxidation of the molybdenum(Iv) complex type $\left[\mathrm{MoO}\left(\mathrm{PMe}_{3}\right) \mathrm{L}_{2}\right]$ with molecular oxygen either results in the formation of $\left[\mathrm{MoO}_{2}\right]^{2+}$ or $\left[\mathrm{MoO}\left(\mathrm{O}_{2}\right)\right]^{2+}$ complexes, ${ }^{12,15}$ depending on the steric demand in the ligand backbone. When benzene- $\mathrm{d}_{6}$ solutions of 2 and 3 were exposed to dry molecular oxygen, color change from crimson to orange for complex 2 and from purple to orange for 3 occurred. ${ }^{1} \mathrm{H}$ and ${ }^{13} \mathrm{C}$ NMR spectra indicate the formation of the same, non-symmetric compound in both reactions, as two sets of resonances for both coordinated ligands are observed (e.g. in the ${ }^{1} \mathrm{H}$ NMR spectra $2 \times \mathrm{Ar}-\mathrm{CHN}$ at 8.55 and $8.63 \mathrm{ppm}$, Table 1). Such behavior is in good accordance to the literature regarding the formation of a $\left[\mathrm{MoO}\left(\mathrm{O}_{2}\right)\right]$-type complex, as the coordination of the $\mathrm{O}_{2}$ molecule in cis position to the $[\mathrm{MoO}]^{2+}$ renders the geometry around the metal center non-symmetric. ${ }^{16}$ It is noteworthy that this $\left[\mathrm{MoO}\left(\mathrm{O}_{2}\right) \mathrm{L}_{2}\right]$ complex 4 can be synthesized directly by reacting 1 with a 5 -fold excess phosphine under $\mathrm{O}_{2}$ atmosphere. After purification, 4 was isolated as an orange solid in 93\% yield (Scheme 3).

Single crystals suitable for X-ray diffraction analyses of complex 4 were obtained from concentrated THF solutions layered with pentane at room temperature. Crystal data and structure refinements are presented in the Experimental section. The structure reveals a hepta-coordinated metal center in a distorted pentagonal bi-pyramidal geometry (Fig. 2). The metal center is ligated by one terminal oxygen atom, a $\eta^{2}$ peroxo moiety and two bidentate Schiff base ligands. The terminal oxygen atom is found to be in cis position to the $\eta^{2}$ peroxo moiety. All these features as well as bonds lengths and angles values are in good accordance with similar $\left[\mathrm{MoO}\left(\mathrm{O}_{2}\right)\right]^{2+}$ complexes reported previously in the literature. ${ }^{10,12,24}$

The re-oxidation of the reduced $\left[\mathrm{MoO}\left(\mathrm{PMe}_{3}\right) \mathrm{L}_{2}\right]$ complex 2 with molecular $\mathrm{O}_{2}$, yielding the $\left[\mathrm{MoO}\left(\mathrm{O}_{2}\right) \mathrm{L}_{2}\right]$ complex 4 (Scheme 3), provided an interesting information. The ${ }^{31} \mathrm{P}$ NMR spectra measured directly after exposition of 2 to $\mathrm{O}_{2}$ showed that the phosphine attached to the Mo is released as a free phosphine when $\mathbf{4}$ is formed. The same NMR sample, maintained under $\mathrm{O}_{2}$ atmosphere was submitted again for analysis after $24 \mathrm{~h}$. The ${ }^{31} \mathrm{P}$ NMR spectra revealed that the equivalent of

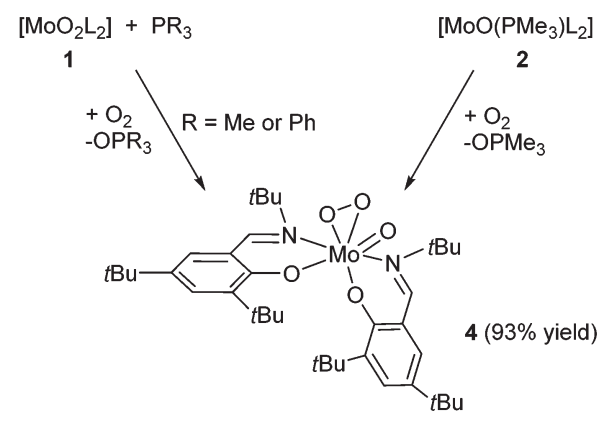

Scheme 3 Synthesis of the oxo-peroxo Mo(vi) complex 4. 


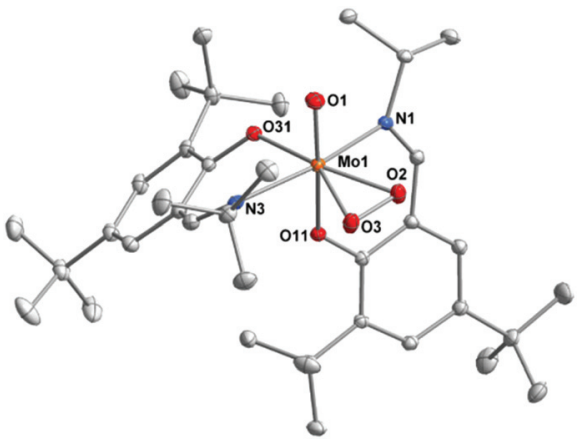

Fig. 2 Molecular structure of complex 4. Thermal ellipsoids have been drawn at $50 \%$ probability level. Hydrogen atoms are omitted for clarity. Selected bond lengths $(\AA)$ and angles $\left({ }^{\circ}\right)$ : Mo1-O1 1.6909(10); Mo1-O2 1.9487(10); Mo1-O3 1.9447(10); Mo1-O11 2.0494(9); Mo1-O31 2.0269(9); Mo1-N1 2.2548(11); Mo1-N2 2.2162(11); O2-O3 1.4332(13); O1-Mo1-O11 170.37(4); O2-Mo1-O31 155.69(4); O3-Mo1-O31 153.96(4); N1-Mo1-N3 165.72(4); O1-Mo1-O2 99.17(5); O1-Mo1-O3 101.82(5); O1-Mo1-O31 91.99(4); O1-Mo1-N1 91.57(4).

free $\mathrm{PMe}_{3}$ formed during the re-oxidation had been converted to $\mathrm{OPMe}_{3}$. Thus, when 2 reacted with $\mathrm{O}_{2}$ as presented in Scheme 3, substitution of the phosphine by $\mathrm{O}_{2}$ occurred and only subsequently $\mathrm{PMe}_{3}$ was oxidized to $\mathrm{OPMe}_{3}$ by the complex 4 (see Fig. S3 in ESI $\dagger$ ). These observations are noteworthy as phosphine is usually strongly coordinated, so that prior oxidation is required for its displacement. Here, the steric demand of the ligand and the trans-effect resulting from the presence of the oxo group leads to a weakly coordinated $\mathrm{PMe}_{3}$ rendering the system reactive. Such labilization of phosphine ligands due to a trans-effect was already observed with other Mo complexes. ${ }^{25}$ The fact that the free $\mathrm{PMe}_{3}$ equivalent could be oxidized under $\mathrm{O}_{2}$ atmosphere in presence of 4 lead us to investigate the role of the oxo-peroxo complex as possible catalyst for the oxidation of phosphine using $\mathrm{O}_{2}$, as described thereafter. In order to exclude auto oxidation of $\mathrm{PMe}_{3}$ and to prove the reactivity of the oxo-peroxo complex in OAT, the reaction of 4 with 2 equiv. $\mathrm{PMe}_{3}$ in exclusion of $\mathrm{O}_{2}$ was investigated (Scheme 4). Monitoring the reaction by ${ }^{1} \mathrm{H}$ and ${ }^{31} \mathrm{P}$ NMR spectroscopy revealed that the oxo-peroxo complex $\mathbf{4}$ is able to oxidize tertiary phosphines, but more importantly that both atoms of the peroxo group are involved in this transfer. Although the reaction does not go to completion, ${ }^{1} \mathrm{H}$ NMR spectra show formation of a new molybdenum species and $\mathrm{OPMe}_{3}$ in a $1: 2$ ratio, along with unreacted $\mathrm{PMe}_{3}$ and complex 4. As shown in Fig. 3, after $t=5 \mathrm{~h}$ approx. $25 \%$ conversion is observed and after $t=30 \mathrm{~h} 50 \%$. This Mo intermediate exhibits a single set of signal very similar to that of the Mo(Iv) monooxo complex 2 (e.g. signals at 8.34, 7.40 and $7.21 \mathrm{ppm}$ ). The small differences between the ${ }^{1} \mathrm{H}$ NMR signals of the observed Mo intermediate and 2 can be explained by differences in the coordination of the phosphine. In the intermediate, $\mathrm{PMe}_{3}$ is only weakly interacting with Mo but is not fully coordinated. This explanation is supported by the ${ }^{1} \mathrm{H}$ NMR signal of the weakly interacting $\mathrm{PMe}_{3}\left(0.86 \mathrm{ppm}, J_{\mathrm{P}-\mathrm{C}}=4.2 \mathrm{~Hz}\right)$, which is different from free $\mathrm{PMe}_{3}\left(0.81 \mathrm{ppm}, J_{\mathrm{P}-\mathrm{C}}<2 \mathrm{~Hz}\right)$ and from the fully bound $\mathrm{PMe}_{3}$ in $2\left(0.91 \mathrm{ppm}, J_{\mathrm{P}-\mathrm{C}}=7 \mathrm{~Hz}\right)$. During the course of the reaction, no formation of a plausible $\mathrm{Mo}(\mathrm{vI})$ dioxo intermediate (complex 1) was observed, indicating that the transfer of the first oxygen atom from the peroxo unit is the rate determining step of the process, while transfer of the second oxygen atom is either concerted or occurs much faster. This was corroborated by kinetic experiments using UV-Vis spectroscopy. The OAT reaction from complex 1 with a 100 -fold excess $\mathrm{PMe}_{3}$ (pseudo-first order conditions) to form the reduced complex 2 was found to have a rate constant $k=0.003$ $\mathrm{s}^{-1}$. The corresponding reaction of complex 4 with 100 equiv. $\mathrm{PMe}_{3}$ and the same concentration for the complex and phosphine was found to be orders of magnitude slower as hardly any reaction occurred in the observed timeframe (see ESI $\dagger$ ).

As both the dioxo and oxo-peroxo complexes are active in OAT reaction, catalytic oxidation of $\mathrm{PMe}_{3}$ was investigated. In the literature, the molybdenum complexes which activate $\mathrm{O}_{2}$ could not catalytically oxidize phosphines. $\left[\mathrm{MoO}\left(\mathrm{O}_{2}\right)(\mathrm{CN})_{4}\right]$ $\left[\mathrm{PPh}_{4}\right]_{2}$ is capable of oxidizing $3 \mathrm{~mol} \mathrm{PPh}_{3}$ per 2 mol molybdenum in the presence of molecular $\mathrm{O}_{2},{ }^{10}$ but no further oxidation of $\mathrm{PPh}_{3}$ was obtained due to conproportionation of the dioxo Mo(vI) and the monoxo Mo(Iv) intermediates. Although $\mathrm{PMe}_{3}$ is easily oxidized without any metal in presence of water and air, the stability of $\mathrm{PMe}_{3}$ against dry $\mathrm{O}_{2}$ in dry benzene- $\mathrm{d}_{6}$ solutions was confirmed by running a blank experiment (see ESI $\dagger$ ). For the catalytic run, a solution of 1 (10 mg, $14 \mu \mathrm{mol})$ in benzene- $\mathrm{d}_{6}$ was prepared and placed under $\mathrm{O}_{2}$ atmosphere. Then 100 equivalents $\mathrm{PMe}_{3}$ were added and the reaction was left to stir for $24 \mathrm{~h}$ (Scheme 5). The reaction was monitored by ${ }^{1} \mathrm{H}$ and ${ }^{31} \mathrm{P} \mathrm{NMR}$ analysis. Integration of $\mathrm{PMe}_{3}$ and $\mathrm{OPMe}_{3}$ signals after $24 \mathrm{~h}$ showed the conversion of 19 equivalents $\mathrm{PMe}_{3}$ to $\mathrm{OPMe}_{3}$. After evaporation of the solvent and unreacted phosphine, mass balance confirmed formation of $\mathrm{OPMe}_{3}$ besides the residue of the catalyst. Control experiments in the presence of sodium molybdate or $\left[\mathrm{MoO}_{2}(\mathrm{acac})_{2}\right]$ did not lead to formation of $\mathrm{OPMe}_{3}$. The reactivity of $\mathbf{1}$ is limited by
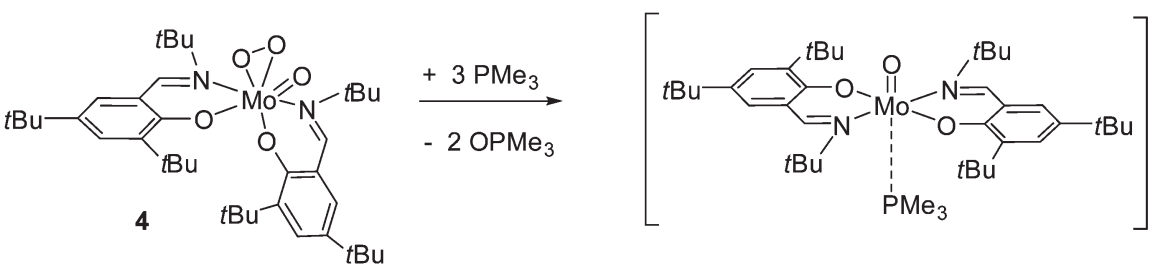

Scheme 4 OAT reaction of the oxo-peroxo complex 4 in exclusion of $\mathrm{O}_{2}$ in benzene- $\mathrm{d}_{6}$. 

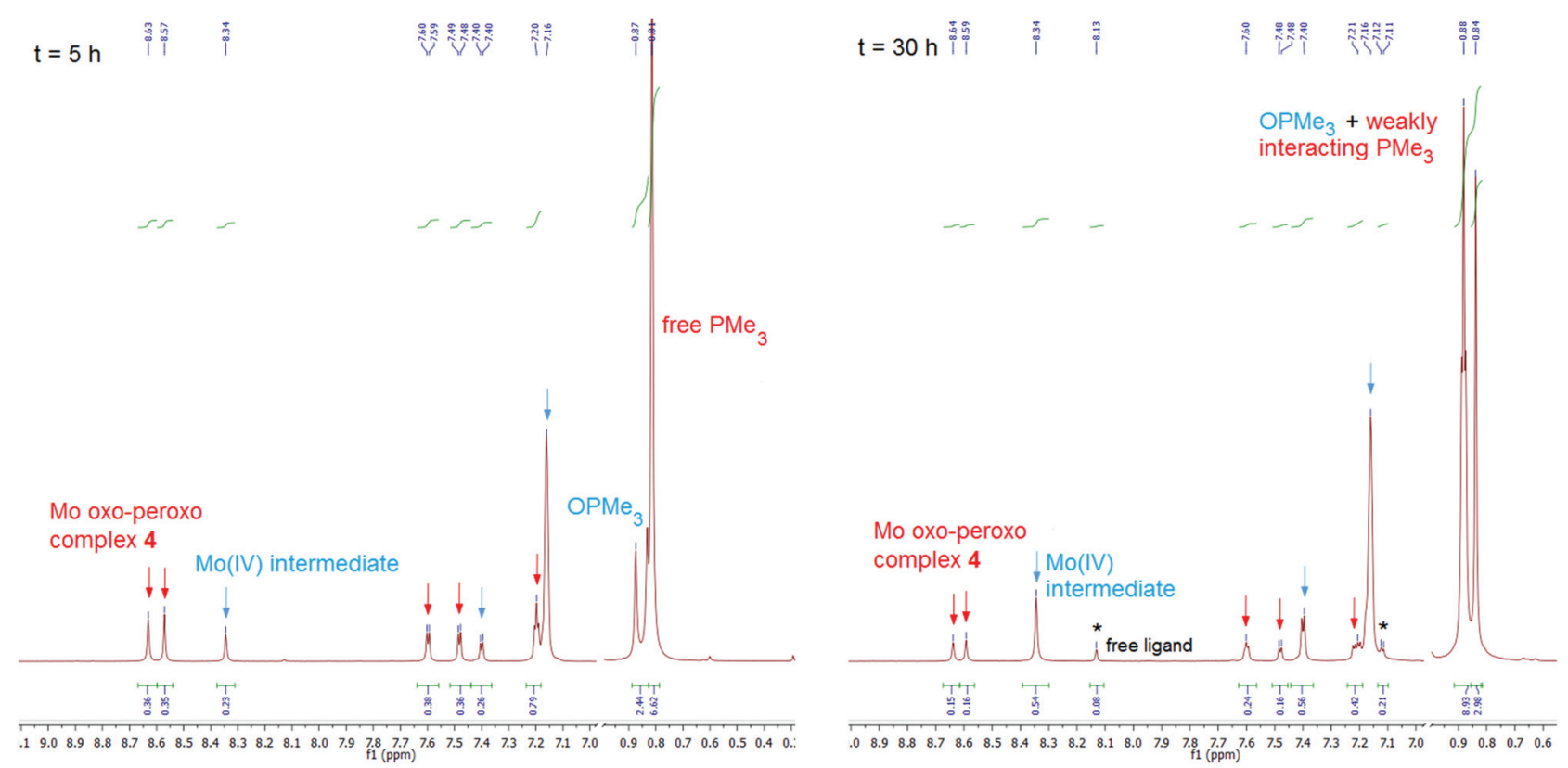

Fig. $3{ }^{1} \mathrm{H}$ NMR spectra in benzene- $\mathrm{d}_{6}$ at $t=5 \mathrm{~h}$ (left) and $t=30 \mathrm{~h}$ (right) of the reaction of molybdenum oxo-peroxo complex 4 with 2 equiv. PMe 3 under $\mathrm{O}_{2}$ exclusion.

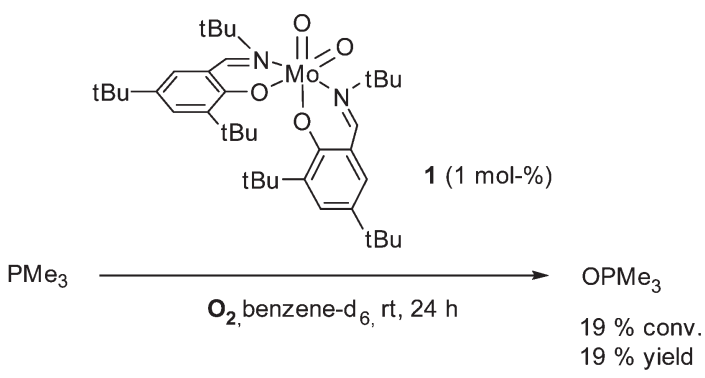

Scheme 5 Conversion of $\mathrm{PMe}_{3}$ to $\mathrm{OPMe}_{3}$ catalyzed by 1 using $\mathrm{O}_{2}$.

decomposition of the complex, but is a successful progress toward the use of molecular oxygen as sole oxidant in catalytic OAT reactions.

\section{Conclusion}

We were able to prepare a new molybdenum(vi) dioxo complex 1 which is active in oxygen atom transfer reaction to tertiary phosphines, allowing the isolation of the unusual trans-[MoO$\left.\left(\mathrm{PMe}_{3}\right) \mathrm{L}_{2}\right]$ complex 2 . The activation of molecular oxygen by the reduced species yields the oxo-peroxo complex $\left[\mathrm{MoO}\left(\mathrm{O}_{2}\right)^{-}\right.$ $\left.\mathrm{L}_{2}\right] \mathbf{4}$ in excellent yield. 4 is also active in OAT and NMR spectroscopy studies show that both atoms of the peroxo group are transferred to phosphine. Hence, the molybdenum (vI) dioxo complex 1 exhibits promising results as catalyst for oxidations using $\mathrm{O}_{2}$ as the oxidant.

\section{Experimental section}

All reactions have been carried out under nitrogen using standard Schlenk or glovebox techniques. $\left[\mathrm{MoO}_{2} \mathrm{Cl}_{2}\right]$ was purchased from Sigma-Aldrich and used in the Glovebox without further purification. The Schiff base ligand was synthesized according to previously published literature. ${ }^{19}$ Solvents were purified via a Pure-Solv MD-4-EN solvent purification system from Innovative Technology, Inc. The ${ }^{1} \mathrm{H}$ and ${ }^{13} \mathrm{C}$ NMR spectra were recorded on a Bruker Optics Instrument $300 \mathrm{MHz}$. Peaks are denoted as singlet (s), doublet (d), doublet of doublets $(\mathrm{dd})$, triplet $(\mathrm{t})$ and multiplet $(\mathrm{m})$, Ar denotes aromatic protons. Chemical shifts are reported in ppm and are referenced using the residual solvent peak. To obtain self-diffusion coefficients we used two-dimensional diffusion ordered spectroscopy (DOSY). ${ }^{26}$ The employed pulse sequence was a bipolar pulse pair longitudinal eddy current delay (BPP-LED) sequence, using 32 scans per increment, $60 \mathrm{~ms}$ diffusion delay time, $1 \mathrm{~ms}$ gradient pulses and variation of the gradient strength in 32 increments, linearly varied between 2 and 95\% of maximum (which is $53.5 \mathrm{G} \mathrm{cm}^{-1}$ ). DOSY analysis was performed using the Bruker DOSY package of TopSpin 3.1. All DOSY measurements were carried out at $300 \mathrm{~K}$ on a Bruker Avance III $500 \mathrm{MHz}$ NMR spectrometer using a $5 \mathrm{~mm}$ TXI probe with $z$-axis gradients. IR spectra were measured as solid samples on a Bruker Alpha P Diamond FTIR-ATR spectrometer or as liquid samples in benzene on a Bruker FT-MIR matrix MF in situ spectrometer using a glass fiber optic probe. ESI-MS spectra were recorded in acetonitrile on an Agilent 1100 Series LCMSD (SL type). Elemental analyses were carried out using a Heraeus Vario Elementar automatic analyzer at the Institute of Inorganic Chemistry at the University of Technology in Graz. 
$\left[\mathrm{MoO}_{2} \mathbf{L}_{2}\right](1)$

Ligand HL (500 mg, $1.7 \mathrm{mmol}, 2$ equiv.) was dissolved in $5 \mathrm{ml}$ of dry toluene and slowly added to a suspension of $\left[\mathrm{MoO}_{2} \mathrm{Cl}_{2}\right]$ (180 mg, $0.9 \mathrm{mmol}, 1$ equiv.) in $5 \mathrm{~mL}$ of dry toluene under inert conditions. Dry triethylamine $(0.26 \mathrm{~mL}, 1.9 \mathrm{mmol}$, 2.2 equiv.) was then added. The formation of the complex was immediately indicated by a quick change of color from pale yellow to deep red. To ensure complete complex formation, the solution was stirred $5 \mathrm{~h}$ at room temperature. The mixture was then filtered with a cannula and the solvent was removed in vacuo. The residue was washed thrice with $10 \mathrm{ml}$ of cold pentane to afford complex 1 as an orange solid in $64 \%$ yield (407 mg). Single crystals suitable for X-ray diffraction analyses were obtained by slow evaporation from concentrated toluene solution at room temperature.

${ }^{1} \mathbf{H}$ NMR (300 MHz, benzene- $\left.d_{6}, \mathrm{ppm}\right) \delta=8.33(\mathrm{~s}, 1 \mathrm{H}, \mathrm{Ar}-$ $\mathrm{CHN}), 7.66\left(\mathrm{~d},{ }^{4} J_{\mathrm{H}-\mathrm{H}}=2.7 \mathrm{~Hz}, 1 \mathrm{H}, \mathrm{Ar}-H\right), 7.15\left(\mathrm{~d},{ }^{4} J_{\mathrm{H}-\mathrm{H}}=2.7\right.$ $\mathrm{Hz}, 1 \mathrm{H}, \mathrm{Ar}-\mathrm{H}), 1.56\left(\mathrm{~s}, 9 \mathrm{H}, \mathrm{NC}\left(\mathrm{CH}_{3}\right)_{3}\right), 1.33\left(\mathrm{~s}, 9 \mathrm{H}, \mathrm{Ar}-\mathrm{C}\left(\mathrm{CH}_{3}\right)_{3}\right)$, $1.30\left(\mathrm{~s}, 9 \mathrm{H}, \mathrm{Ar}-\mathrm{C}\left(\mathrm{CH}_{3}\right)_{3}\right)$.

${ }^{13} \mathrm{C}$ NMR (75 MHz, benzene- $\left.d_{6}, \mathrm{ppm}\right) \delta=167.48(\mathrm{Ar}-\mathrm{CHN})$, 164.31 (Ar-O), 139.32 (Ar), 139.00 (Ar), 131.03 (Ar-H), 129.28 $(A r-\mathrm{H}), 123.39(\mathrm{Ar}), 64.96\left(\mathrm{NC}\left(\mathrm{CH}_{3}\right)_{3}\right), 35.28\left(\mathrm{Ar}-\mathrm{C}\left(\mathrm{CH}_{3}\right)_{3}\right), 34.18$ $\left(\mathrm{Ar}-\mathrm{C}\left(\mathrm{CH}_{3}\right)_{3}\right), \quad 31.59 \quad\left(\mathrm{Ar}-\mathrm{C}\left(\mathrm{CH}_{3}\right)_{3}\right), \quad 31.24 \quad\left(\mathrm{~N}\left(\mathrm{CH}_{3}\right)_{3}\right), \quad 29.57$ $\left(\mathrm{Ar}-\mathrm{C}\left(\mathrm{CH}_{3}\right)_{3}\right)$.

IR (ATR, $\left.\mathrm{cm}^{-1}\right): \nu=1613(\mathrm{~m}, \mathrm{C}=\mathrm{N}), 1587(\mathrm{~m}, \mathrm{C}=\mathrm{N}), 1534$ (m), $1387(\mathrm{~m}), 1255(\mathrm{~m}), 1169$ (s), 913 (s, Mo=O), 883 (s, $\mathrm{Mo}=\mathrm{O}), 836(\mathrm{~m}), 745(\mathrm{~m}), 533(\mathrm{~m})$.

Anal. Calcd for $\mathrm{MoO}_{4} \mathrm{~N}_{2} \mathrm{C}_{38} \mathrm{H}_{60}: \mathrm{C}, 64.75 ; \mathrm{H}, 8.58 ; \mathrm{N}, 3.97$. Found: C, 64.29; H, 8.42; N, 3.73\%.

\section{$\left[\mathrm{MoO}\left(\mathrm{PMe}_{3}\right) \mathbf{L}_{2}\right](2)$}

$\left[\mathrm{MoO}_{2} \mathrm{~L}_{2}\right]$ (100 mg, $0.14 \mathrm{mmol}, 1$ equiv.) was dissolved in dry toluene and excess $\mathrm{PMe}_{3}(70 \mu \mathrm{L}, 0.7 \mathrm{mmol}, 5$ equiv.) was added. The OAT was indicated by a quick change of color from orange to dark red. After stirring for 3 hours, the solvent and excess $\mathrm{PMe}_{3}$ were removed under reduced pressure. The obtained material was re-dissolved in cold dry heptane $(5 \mathrm{~mL})$ and filtered over a pad of Celite. After evaporation of the solvent, complex 2 was obtained as dark red solid. Yield: $95 \mathrm{mg}(87 \%)$.

${ }^{1}$ H NMR (300 MHz, benzene- $\left.d_{6}, \mathrm{ppm}\right) \delta=8.32$ (s, 2H, Ar$\mathrm{C} H \mathrm{~N}), 7.40\left(\mathrm{~d},{ }^{4} J_{\mathrm{H}-\mathrm{H}}=2.6 \mathrm{~Hz}, 2 \mathrm{H}, \mathrm{Ar}-H\right), 7.16(\mathrm{~m}, 2 \mathrm{H}, \mathrm{Ar}-H)$, $1.65\left(\mathrm{~s}, 18 \mathrm{H}, \mathrm{N}-\mathrm{C}\left(\mathrm{CH}_{3}\right)_{3}\right), 1.34\left(\mathrm{~s}, 18 \mathrm{H}, \mathrm{Ar}-\mathrm{C}\left(\mathrm{CH}_{3}\right)_{3}\right), 1.31(\mathrm{~s}$, $\left.18 \mathrm{H}, \mathrm{Ar}-\mathrm{C}\left(\mathrm{CH}_{3}\right)_{3}\right), 0.91\left(\mathrm{~d}, J_{\mathrm{P}-\mathrm{H}}=7 \mathrm{~Hz}, 9 \mathrm{H}, \mathrm{OPMe}_{3}\right)$.

${ }^{13} \mathrm{C}$ NMR (75 MHz, benzene- $\left.d_{6}, \mathrm{ppm}\right) \delta=164.57$ (Ar-CHN), 162.96 (Ar-O), 138.78 (Ar), $136.58(A r), 131.55(A r-\mathrm{H}), 128.90$ $(A r-\mathrm{H}), 122.59(\mathrm{Ar}), 64.47\left(\mathrm{~N}-\mathrm{C}\left(\mathrm{CH}_{3}\right)_{3}\right), 35.67\left(\mathrm{Ar}-\mathrm{C}\left(\mathrm{CH}_{3}\right)_{3}\right)$, $34.05\left(\mathrm{Ar}-\mathrm{C}\left(\mathrm{CH}_{3}\right)_{3}\right), 32.07\left(\mathrm{Ar}-\mathrm{C}\left(\mathrm{CH}_{3}\right)_{3}\right), 31.81\left(\mathrm{~N}-\mathrm{C}\left(\mathrm{CH}_{3}\right)_{3}\right)$, $30.60\left(\mathrm{Ar}-\mathrm{C}\left(\mathrm{CH}_{3}\right)_{3}\right), 17.55\left(\mathrm{~d}, \mathrm{~J}_{\mathrm{P}-\mathrm{C}}=17.9 \mathrm{~Hz}, \mathrm{Mo}-\mathrm{P}\left(\mathrm{CH}_{3}\right)_{3}\right)$.

${ }^{31}$ P NMR (121 MHz, benzene- $\left.d_{6}, 298 \mathrm{~K}, \mathrm{ppm}\right) \delta-9.47$ (Mo $\left.P\left(\mathrm{CH}_{3}\right)_{3}\right)$.

IR (FT-IR, benzene, $\left.\mathrm{cm}^{-1}\right): \nu 1605(\mathrm{~m}, \mathrm{C}=\mathrm{N}), 1542(\mathrm{~m}), 1460$ (s), 1436 (s), 1396 (s), 1362 (m), 1307 (s), 1256 (s), 1165 (s), 932 $(\mathrm{s}, \mathrm{Mo}=\mathrm{O}), 836(\mathrm{~m})$.

ESI-MS (50 V) m/z (\%): $690.3(100)\left[\mathrm{M}-\mathrm{HP}\left(\mathrm{CH}_{3}\right)_{3}\right]$.
Anal. Calcd for $\mathrm{MoO}_{3} \mathrm{~N}_{2} \mathrm{PC}_{41} \mathrm{H}_{69}$ : C, 64.38; H, 9.09; N, 3.66. Found: C, 64.25; H, 9.23; N, 3.38\%.

\section{$\left[\mathrm{MoOL}_{2}\right](3)$}

$\left[\mathrm{MoO}_{2} \mathrm{~L}_{2}\right]$ (100 mg, $0.14 \mathrm{mmol}, 1$ equiv.) was dissolved in dry toluene and an excess $\mathrm{PPh}_{3}$ (74 mg, $0.28 \mathrm{mmol}, 2$ equiv.) was added. The OAT was indicated by a quick change of color from orange to purple. After stirring for 15 hours, the solvent was removed under reduced pressure. The obtained material was re-dissolved in cold dry heptane $(5 \mathrm{~mL})$ and filtered over a pad of celite. After evaporation of the heptane, $\left[\mathrm{MoOL}_{2}\right]$ was obtained as a purple solid in $60 \%$ yield, with partial decomposition to the free ligand and traces of triphenylposphine.

${ }^{1}$ H NMR (300 MHz, benzene- $\left.d_{6}, \mathrm{ppm}\right) \delta=8.21(\mathrm{~s}, 2 \mathrm{H}$, $\mathrm{Ar}-\mathrm{CHN}), 7.47\left(\mathrm{~d},{ }^{4} J_{\mathrm{H}-\mathrm{H}}=2.6 \mathrm{~Hz}, 2 \mathrm{H}, \mathrm{Ar}-H\right), 7.24\left(\mathrm{~d},{ }^{4} J_{\mathrm{H}-\mathrm{H}}=\right.$ $2.6 \mathrm{~Hz}, 2 \mathrm{H}, \mathrm{Ar}-\mathrm{H}), 1.61\left(\mathrm{~s}, 18 \mathrm{H}, \mathrm{N}-\mathrm{C}\left(\mathrm{CH}_{3}\right)_{3}\right), 1.34(\mathrm{~s}, 18 \mathrm{H}$, $\left.\mathrm{Ar}-\mathrm{C}\left(\mathrm{CH}_{3}\right)_{3}\right), 1.33\left(\mathrm{~s}, 18 \mathrm{H}, \mathrm{Ar}-\mathrm{C}\left(\mathrm{CH}_{3}\right)_{3}\right)$.

${ }^{13} \mathrm{C}$ NMR (75 MHz, benzene- $\left.d_{6}, \mathrm{ppm}\right) \delta=165.66(\mathrm{Ar}-\mathrm{CHN})$, 163.68 (Ar-O), 139.01 (Ar), 138.52 (Ar), 132.05 (Ar-H), 129.07 $(A r-\mathrm{H}), 119.06(\mathrm{Ar}), 65.97\left(\mathrm{~N}-\mathrm{C}\left(\mathrm{CH}_{3}\right)_{3}\right), 35.80\left(\mathrm{Ar}-\mathrm{C}\left(\mathrm{CH}_{3}\right)_{3}\right)$, $34.27\left(\mathrm{Ar}-\mathrm{C}\left(\mathrm{CH}_{3}\right)_{3}\right), 31.69\left(\mathrm{Ar}-\mathrm{C}\left(\mathrm{CH}_{3}\right)_{3}\right), 30.83\left(\mathrm{~N}-\mathrm{C}\left(\mathrm{CH}_{3}\right)_{3}\right)$, $30.14\left(\mathrm{Ar}-\mathrm{C}\left(\mathrm{CH}_{3}\right)_{3}\right)$.

\section{$\left[\mathrm{MoO}\left(\mathrm{O}_{2}\right) \mathbf{L}_{2}\right](4)$}

$\left[\mathrm{MoO}_{2} \mathrm{~L}_{2}\right]$ (100 mg, $0.14 \mathrm{mmol}, 1$ equiv.) was dissolved in dry benzene $(5 \mathrm{~mL})$ followed by the addition of excess $\mathrm{PMe}_{3}$ (53 mg, $70 \mu \mathrm{L}, 0.70 \mathrm{mmol}, 5$ equiv.). The OAT was indicated by a quick change of color from orange to dark red. The solution was stirred for 30 minutes, followed by exposure of this solution to dry molecular oxygen for 5 minutes. The reaction solution quickly changed the color from dark violet to orange. The mixture was left to stir for 30 minutes and the solvent was removed in vacuo. The product was dissolved in heptane $(5 \mathrm{~mL})$ and twice filtered over a pad of Celite. $\left[\mathrm{MoO}\left(\mathrm{O}_{2}\right) \mathrm{L}_{2}\right]$ was obtained as an orange solid. Yield: $87 \mathrm{mg}$ (93\%). For elemental analyses, the complex was dissolved in minimum amount of $\mathrm{CH}_{2} \mathrm{Cl}_{2}$ and again filtered over a pad of Celite. Single crystals suitable for X-ray diffraction analyses were obtained from concentrated THF solutions layered with pentane.

${ }^{1}$ H NMR (300 MHz, benzene- $\left.d_{6}, \mathrm{ppm}\right) \delta=8.63$ (s, 1H, Ar$\mathrm{CHN}), 8.55(\mathrm{~s}, 1 \mathrm{H}, \mathrm{Ar}-\mathrm{CHN}), 7.60\left(\mathrm{~d},{ }^{4} J_{\mathrm{H}-\mathrm{H}}=2.4 \mathrm{~Hz}, 1 \mathrm{H}, \mathrm{Ar}-H\right)$, $7.49\left(\mathrm{~d},{ }^{4} J_{\mathrm{H}-\mathrm{H}}=2.4 \mathrm{~Hz}, 1 \mathrm{H}, \mathrm{Ar}-H\right), 7.19\left(\mathrm{~d},{ }^{4} J_{\mathrm{H}-\mathrm{H}}=2.4 \mathrm{~Hz}, 2 \mathrm{H}\right.$, $\mathrm{Ar}-\mathrm{H}), 1.87$ (s, 9H, $\left.\mathrm{NC}\left(\mathrm{CH}_{3}\right)_{3}\right), 1.74$ (s, 9H, $\left.\mathrm{NC}\left(\mathrm{CH}_{3}\right)_{3}\right), 1.41$ (s, 9H, $\left.\mathrm{Ar}-\mathrm{C}\left(\mathrm{CH}_{3}\right)_{3}\right), 1.27$ (s, 9H, $\left.\mathrm{Ar}-\mathrm{C}\left(\mathrm{CH}_{3}\right)_{3}\right), 1.23$ (s, 9H, $\left.\mathrm{Ar}-\mathrm{C}\left(\mathrm{CH}_{3}\right)_{3}\right), 1.09\left(\mathrm{~s}, 9 \mathrm{H}, \mathrm{Ar}-\mathrm{C}\left(\mathrm{CH}_{3}\right)_{3}\right)$.

${ }^{13} \mathrm{C}$ NMR (75 MHz, benzene- $d_{6}$, ppm) $\delta=166.36$ (overlapping signals, $2 \times \mathrm{Ar}-\mathrm{CHN}), 161.74(\mathrm{Ar}-\mathrm{O}), 159.65(\mathrm{Ar}-\mathrm{O}), 140.22$ (Ar), 139.79 (Ar), 138.97 (Ar), 137.78 (Ar), $131.83($ Ar-H), 130.86 $(A r-\mathrm{H}), 130.16(A r-\mathrm{H}), 130.37(A r-\mathrm{H}), 124.45(A r), 122.63(A r)$, $67.96\left(\mathrm{NC}\left(\mathrm{CH}_{3}\right)_{3}\right), 67.49\left(\mathrm{NC}\left(\mathrm{CH}_{3}\right)_{3}\right), 35.44\left(\mathrm{Ar}-C\left(\mathrm{CH}_{3}\right)_{3}\right), 34.77$ $\left(\mathrm{Ar}-\mathrm{C}\left(\mathrm{CH}_{3}\right)_{3}\right), 34.13\left(\mathrm{Ar}-\mathrm{C}\left(\mathrm{CH}_{3}\right)_{3}\right), 34.06\left(\mathrm{Ar}-\mathrm{C}\left(\mathrm{CH}_{3}\right)_{3}\right), 32.78$ $\left(\mathrm{NC}\left(\mathrm{CH}_{3}\right)_{3}\right), 31.60\left(\mathrm{NC}\left(\mathrm{CH}_{3}\right)_{3}\right), 31.54\left(2 \times \mathrm{Ar}-\mathrm{C}\left(\mathrm{CH}_{3}\right)_{3}\right), 30.25$ $\left(\mathrm{Ar}-\mathrm{C}\left(\mathrm{CH}_{3}\right)_{3}\right), 29.91\left(\mathrm{Ar}-\mathrm{C}\left(\mathrm{CH}_{3}\right)_{3}\right)$.

IR (ATR, cm $\left.{ }^{-1}\right): \nu 1606(\mathrm{~s}, \mathrm{C}=\mathrm{N}), 1541(\mathrm{~m}), 1255$ (s), 1168 (s), $931(\mathrm{~s}, \mathrm{Mo}=\mathrm{O}), 838(\mathrm{~s}), 777(\mathrm{~s}), 747(\mathrm{~m}), 542(\mathrm{~s}, \mathrm{Mo}-\mathrm{O})$. 
Anal. Calcd for $\mathrm{MoO}_{5} \mathrm{~N}_{2} \mathrm{C}_{38} \mathrm{H}_{60} \cdot 0.23 \mathrm{CH}_{2} \mathrm{Cl}_{2}$ : C, 62.00; H, 8.23; N, 3.78. Found: C, 62.18; H, 8.44; N, 3.90\%.

\section{Oxygen atom transfer reactivity of $\left[\mathrm{MoO}\left(\mathrm{O}_{2}\right) \mathrm{L}_{2}\right](4)$}

$\left[\mathrm{MoO}\left(\mathrm{O}_{2}\right) \mathrm{L}_{2}\right](25 \mathrm{mg}, 0.035 \mathrm{mmol}, 1$ equiv.) was dissolved in dry benzene- $\mathrm{d}_{6}$ under inert conditions in a Young NMR tube. 2 equivalent $\mathrm{PMe}_{3}(8 \mu \mathrm{L}, 0.07 \mathrm{mmol})$ was added using a micropipette. The OAT reaction was monitored by ${ }^{1} \mathrm{H}$ and ${ }^{31} \mathrm{P}$ NMR spectroscopy.

\section{Catalytic oxidation of trimethylphosphine}

$\left[\mathrm{MoO}_{2} \mathrm{~L}_{2}\right]$ (complex 1, $10 \mathrm{mg}, 14 \mu \mathrm{mol}$ ) was placed in a Schlenk flask in the glovebox. The Schlenk flask was evacuated then refilled with dry $\mathrm{O}_{2}$. Dry benzene- $\mathrm{d}_{6}(2 \mathrm{~mL})$ and trimethylphosphine ( $108 \mathrm{mg}, 0.15 \mu \mathrm{L}, 1.4 \mathrm{mmol}, 100$ equiv.) were added and the reaction was left to stir under $\mathrm{O}_{2}$ atmosphere for $24 \mathrm{~h}$. The reaction was monitored by ${ }^{1} \mathrm{H}$ and ${ }^{31} \mathrm{P}$ NMR at $t=4 \mathrm{~h}, 20 \mathrm{~h}$ and $24 \mathrm{~h}$. After removal of the solvent, the mass balance was calculated and the yield of $\mathrm{OPMe}_{3}$ confirmed by integration of the signals in the ${ }^{1} \mathrm{H}$ NMR spectrum at $t=24 \mathrm{~h}$ (yield $=19 \%$ ). To confirm the stability of $\mathrm{PMe}_{3}$ under $\mathrm{O}_{2}$ atmosphere, a blank experiment was performed. A Schlenk flask was evacuated then refilled with dry $\mathrm{O}_{2}$. Dry benzene- $\mathrm{d}_{6}(2 \mathrm{~mL})$ and trimethylphosphine (108 mg, $0.15 \mu \mathrm{L}, 1.4 \mathrm{mmol}, 100$ equiv.) were added and the reaction was left to stir under $\mathrm{O}_{2}$ atmosphere for $24 \mathrm{~h}$. The reaction was monitored by ${ }^{1} \mathrm{H}$ and ${ }^{31} \mathrm{P}$ NMR at $t=4 \mathrm{~h}, 20 \mathrm{~h}$ and $24 \mathrm{~h}$. at $t=24 \mathrm{~h}$, a signal for $\mathrm{OPMe}_{3}$ could be observed in the ${ }^{1} \mathrm{H}$ NMR (1\% yield) but no signal was observed in ${ }^{31} \mathrm{P}$ NMR. After $24 \mathrm{~h}$, the solvent and free $\mathrm{PMe}_{3}$ were evaporated, no solid $\mathrm{OPMe}_{3}$ could be isolated.

\section{OAT kinetic study}

In the glovebox, a solution of $7 \mathrm{mg}$ of complex 1 in $5 \mathrm{~mL}$ toluene $\left(2 \times 10^{-3} \mathrm{~mol} \mathrm{~L}^{-1}\right)$ and a solution of $15 \mathrm{mg} \mathrm{PMe}_{3}$ in $1 \mathrm{~mL}$ toluene $\left(0.2 \mathrm{~mol} \mathrm{~L}^{-1}\right)$ were prepared. Using a micropipette, $100 \mu \mathrm{L}$ of the solution containing the complex were placed in a quartz cuvette and $2 \mathrm{~mL}$ toluene were added. Then $100 \mu \mathrm{L}$ of the solution containing $\mathrm{PMe}_{3}$ were added and the cuvette was sealed with a Teflon stopper and parafilm. The sample was removed from the glovebox and the measurement immediately started. The reaction was monitored by the dissapearance of the signal at $430 \mathrm{~nm}$, at room temperature using a Cary50 Conc. UV-Vis spectrophotometer under PC control using the kinetics program "Scan" included with the instrument software. The same procedure was followed preparing a solution of $7 \mathrm{mg}$ of complex 4 in $5 \mathrm{~mL}$ toluene $\left(2 \times 10^{-3} \mathrm{~mol} \mathrm{~L}^{-1}\right)$.

\section{Structure determination}

For X-ray structure analyses the crystals were mounted onto the tip of glass fiber and data collection was performed at $100 \mathrm{~K}$ using graphite monochromated $\mathrm{Mo} \mathrm{K}_{\alpha}$ radiation $(\lambda=$ $0.71073 \AA$ Å) with a BRUKER-AXS SMART APEX II diffractometer equipped with a CCD detector. Essential details of the crystaldata and structure refinements for compounds $\mathbf{1}$ and $\mathbf{4}$ are summarized in Table 2. Crystallographic data for the structures of compounds $\mathbf{1}$ and $\mathbf{4}$ have been deposited with the
Table 2 Crystallographic data and structure refinements for complexes 1 and 4

\begin{tabular}{|c|c|c|}
\hline & 1 & 4 \\
\hline Empirical formula & $\mathrm{C}_{38} \mathrm{H}_{60} \mathrm{MoN}_{2} \mathrm{O}_{4}$ & $\begin{array}{l}2 \mathrm{MoO}_{5} \mathrm{~N}_{2} \mathrm{C}_{38} \mathrm{H}_{60} \\
x \mathrm{C}_{4} \mathrm{H}_{8} \mathrm{O} \cdot \\
(1-x) \mathrm{C}_{5} \mathrm{H}_{12} \\
x=0.786(6)\end{array}$ \\
\hline Formula weight & 704.82 & 1513.75 \\
\hline Crystal description & Plate, red & Block, red \\
\hline Crystal size (mm) & $0.27 \times 0.17 \times 0.05 \mathrm{~mm}$ & $0.32 \times 0.25 \times 0.25$ \\
\hline $\begin{array}{l}\text { Crystal system, space } \\
\text { group }\end{array}$ & $\begin{array}{l}\text { Monoclinic, } \\
P 21 / n\end{array}$ & $\begin{array}{l}\text { Monoclinic, } \\
C 2 / c\end{array}$ \\
\hline \multicolumn{3}{|l|}{ Unit cell dimensions } \\
\hline$a(\AA)$ & $10.3863(4)$ & $24.3085(13)$ \\
\hline$b(\AA)$ & $11.4627(5)$ & $15.8102(8)$ \\
\hline$c(\AA)$ & $33.1945(13)$ & $20.8035(11)$ \\
\hline$\alpha\left({ }^{\circ}\right)$ & 90 & 90 \\
\hline$\beta\left({ }^{\circ}\right)$ & 98.6499(17) & $94.112(2)$ \\
\hline$\gamma\left({ }^{\circ}\right)$ & 90 & 90 \\
\hline Volume $\left(\AA^{3}\right)$ & $3907.0(3)$ & $7974.7(7)$ \\
\hline $\begin{array}{l}Z \text {, calculated density } \\
\left(\mathrm{g} \mathrm{cm}^{-3}\right)\end{array}$ & $4,1.198$ & $4,1.261$ \\
\hline$F(000)$ & 1504 & 3233.9 \\
\hline $\begin{array}{l}\text { Linear absorption } \\
\text { coefficient } \mu\left(\mathrm{mm}^{-1}\right)\end{array}$ & 0.373 & 0.373 \\
\hline Absorption correction & $\begin{array}{l}\text { Semi-empirical } \\
\text { from equiv. }\end{array}$ & $\begin{array}{l}\text { Semi-empirical } \\
\text { from equiv. }\end{array}$ \\
\hline Temperature (K) & 100 & 100 \\
\hline Wavelength $\left(\right.$ Mo Ko $\left._{\alpha}\right)(\AA)$ & 0.71073 & 0.71073 \\
\hline $\begin{array}{l}\text { Theta range for data } \\
\text { collection }\left(^{\circ}\right)\end{array}$ & 2.46 to 28.45 & 1.79 to 30.00 \\
\hline Limiting indices & $\begin{array}{l}-12 \leq h \leq 12 \\
-5 \leq k \leq 14 \\
-40 \leq l \leq 40\end{array}$ & $\begin{array}{l}-34 \leq h \leq 29 \\
-22 \leq k \leq 22 \\
-29 \leq l \leq 29\end{array}$ \\
\hline $\begin{array}{l}\text { Reflections collected/ } \\
\text { unique }\end{array}$ & $267 \overline{91} / 7 \overline{6} 61$ & $466 \overline{7} / 11648$ \\
\hline Reflections with $I>2 \sigma(I)$ & 5550 & 10882 \\
\hline$R($ int $), R($ sigma $)$ & $0.0549,0.0723$ & $0.0187,0.0148$ \\
\hline $\begin{array}{l}\text { Completeness to theta } \\
\text { max. }\end{array}$ & 0.999 & 0.999 \\
\hline Refinement method & $\begin{array}{l}\text { Full matrix least } \\
\text { squares on } F^{2}\end{array}$ & $\begin{array}{l}\text { Full matrix least } \\
\text { squares on } F^{2}\end{array}$ \\
\hline $\begin{array}{l}\text { Data/restraints/ } \\
\text { parameters }\end{array}$ & $7661 / 432 / 0$ & $11648 / 486 / 12$ \\
\hline Goodness-of-fit on $F^{2}$ & 1.107 & 1.100 \\
\hline Final $R_{1} w R_{2}[I>2 \sigma(I)]$ & $\begin{array}{l}R_{1}=0.0585 \\
\mathrm{w} R_{2}=0.1401\end{array}$ & $\begin{array}{l}R_{1}=0.0277 \\
\mathrm{w} R_{2}=0.0689\end{array}$ \\
\hline$R$ indices (all data) & $\begin{array}{l}R_{1}=0.0869 \\
\mathrm{w} R_{2}=0.1507\end{array}$ & $\begin{array}{l}R_{1}=0.0304 \\
\mathrm{w} R_{2}=0.0709\end{array}$ \\
\hline $\begin{array}{l}\text { Largest diff. peak and } \\
\text { hole }\left(\mathrm{e} \AA^{-3}\right)\end{array}$ & 1.484 and -2.767 & 1.283 and -0.599 \\
\hline
\end{tabular}

Cambridge Crystallographic Data Center [CCDC 1413968 for 1, CCDC 1413969 for 4].

Crystal structure determination of $\mathbf{1}$. The structure was solved by direct methods (SHELXS-97) and refined by fullmatrix least-squares techniques against $F^{2}$ (SHELXL-2014/6). The non-hydrogen atoms were refined with anisotropic displacement parameters without any constraints. The $\mathrm{H}$ atoms of the phenyl rings as well as the $\mathrm{H}$ atoms bonded to the $\mathrm{C}$ atom of a $\mathrm{C}=\mathrm{N}$ double bond were put at the external bisectors of the $\mathrm{C}-\mathrm{C}-\mathrm{X}$ angles at $\mathrm{C}-\mathrm{H}$ distances of $0.95 \AA$ and common isotropic displacement parameters were refined for these $\mathrm{H}$ atoms of the same ligand. The $\mathrm{H}$ atoms of the methyl groups were refined with common isotropic displacement parameters 
for the $\mathrm{H}$ atoms of the same tert-butyl group and idealized geometries with tetrahedral angles, enabling rotation around the $\mathrm{C}-\mathrm{C}$ bonds, and $\mathrm{C}-\mathrm{H}$ distances of $0.98 \AA$.

Crystal structure determination of 4 . The structure could be solved (SHELXS-97) by interpretation of the patterson map (second solution) in the non-centrosymmetric space group $C 2$, but not in centrosymmetric $C 2 / c$. After completion of the molecule an inversion center could be detected and the structure was refined by full-matrix least-squares techniques against $F^{2}$ (SHELXL-2014/6) in the centric space group $C 2 / c$ after an appropriate shift of the origin. A void of approx. $188 \AA^{3}$ is occupied by a THF molecule disordered over two orientations lying near a center of symmetry or by a $n$-pentane molecule at the inversion center. The ratio of the refined occupation factors is $0.768(6)$ to $0.232(6)$. The non-hydrogen atoms of the solvent molecules were refined with isotropic displacement parameters with some restraints. The $\mathrm{H}$ atoms of the solvent molecules were included at calculated positions with their isotropic displacement parameters fixed to 1.2 times $U_{\text {eq }}$ of the $\mathrm{C}$ atom they are bonded to. The non-hydrogen atoms of the metal complex were refined with anisotropic displacement parameters without any constraints. The $\mathrm{H}$ atoms of the phenyl rings were put at the external bisectors of the $\mathrm{C}-\mathrm{C}-\mathrm{C}$ angles at $\mathrm{C}-\mathrm{H}$ distances of $0.95 \AA$ and common isotropic displacement parameters were refined for the $\mathrm{H}$ atoms of the same ring. The $\mathrm{H}$ atoms $\mathrm{H} 10$ and $\mathrm{H} 30$ were put at the external bisector of the $\mathrm{C}-\mathrm{C}-\mathrm{C}$ angle at a $\mathrm{C}-\mathrm{H}$ distance of $0.95 \AA$ but the individual isotropic displacement parameters were free to refine. The $\mathrm{H}$ atoms of the methyl groups were refined with common isotropic displacement parameters for the $\mathrm{H}$ atoms of the same group and idealized geometries with tetrahedral angles, enabling rotation around the $\mathrm{C}-\mathrm{C}$ bond, and C-H distances of $0.98 \AA$.

\section{Acknowledgements}

The authors gratefully acknowledge financial support from the Austrian Science Fund (FWF): project number P26264 and from NAWI Graz.

\section{Notes and references}

1 M. Amini, M. M. Haghdoost and M. Bagherzadeh, Coord. Chem. Rev., 2013, 257, 1093.

2 M. Schubert, J. Leppin, K. Wehming, D. Schollmeyer, K. Heinze and S. R. Waldvogel, Angew. Chem., Int. Ed., 2014, 53, 2494; R. Sanz and M. Pedrosa, Curr. Org. Synth., 2009, 6, 239.

3 R. Hille, Dalton Trans., 2013, 42, 3029; M. J. Romão, Dalton Trans., 2009, 4053; R. H. Holm, Coord. Chem. Rev., 1990, 100, 183; R. Hille, Trends Biochem. Sci., 2002, 27, 360.

4 F. J. Hine, A. J. Taylor and C. D. Garner, Coord. Chem. Rev., 2010, 254, 1570; P. Basu and S. J. N. Burgmayer, Coord. Chem. Rev., 2011, 255, 1016; R. Hille, J. Hall and P. Basu, Chem. Rev., 2014, 114, 3963.
5 J. H. Enemark, J. J. A. Cooney, J.-J. Wang and R. H. Holm, Chem. Rev., 2004, 104, 1175; H. Sugimoto and H. Tsukube, Chem. Soc. Rev., 2008, 37, 2609; C. Schulzke, Eur. J. Inorg. Chem., 2011, 1189; R. H. Holm, E. I. Solomon, A. Majumdar and A. Tenderholt, Coord. Chem. Rev., 2011, 255, 993; S. J. N. Burgmayer, M. Kim, R. Petit, A. Rothkopf, A. Kim, S. Bel Hamdounia, Y. Hou, A. Somogyi, D. HabelRodriguez, A. Williams and M. L. Kirk, J. Inorg. Biochem., 2007, 101, 1601; J. M. Berg and R. H. Holm, J. Am. Chem. Soc., 1985, 107, 925; A. Majumdar and S. Sarkar, Coord. Chem. Rev., 2011, 255, 1039.

6 J. Kollar, US 3351635, 1967; M. N. Sheng and J. G. Zajacek, GB 1136923, 1965; J.-M. Brégeault, Dalton Trans., 2003, 3289; S. Shylesh, M. Jia and W. R. Thiel, Eur. J. Inorg. Chem., 2010, 4395.

7 S. A. Hauser, M. Cokoja and F. E. Kühn, Catal. Sci. Technol., 2013, 3, 552 .

8 I. W. C. E. Arends and R. A. Sheldon, in Modern Oxidation Methods, ed. J.-E. Bäckvall, Wiley-VCH Verlag $\mathrm{GmbH} \& \mathrm{Co}$. KGaA, Weinheim, Germany, 2010, pp. 147-185; W. B. Tolman, Activation of small molecules. Organometallic and bioinorganic perspectives, Wiley-VCH Verlag $\mathrm{GmbH} \&$ Co. KGaA, Weinheim, Germany, 2006.

9 J. Serrano-Plana, I. Garcia-Bosch, A. Company and M. Costas, Acc. Chem. Res., 2015, 48, 2397; W. Nam, Acc. Chem. Res., 2015, 48, 2415; E. I. Solomon, D. E. Heppner, E. M. Johnston, J. W. Ginsbach, J. Cirera, M. Qayyum, M. T. Kieber-Emmons, C. H. Kjaergaard, R. G. Hadt and L. Tian, Chem. Rev., 2014, 114, 3659; K. Ray, F. F. Pfaff, B. Wang and W. Nam, J. Am. Chem. Soc., 2014, 136, 13942; P. Comba, Y.-M. Lee, W. Nam and A. Waleska, Chem. Commun., 2014, 50, 412; K. E. Dalle, T. Gruene, S. Dechert, S. Demeshko and F. Meyer, J. Am. Chem. Soc., 2014, 136, 7428; P. Haack and C. Limberg, Angew. Chem., Int. Ed., 2014, 53, 4282; C. E. MacBeth, A. P. Golombek, V. G. Young Jr., C. Yang, K. Kuczera, M. P. Hendrich and A. S. Borovik, Science, 2000, 289, 938; E. I. Solomon, P. Chen, M. Metz, S.-K. Lee and A. E. Palmer, Angew. Chem., Int. Ed., 2001, 40, 4570.

10 H. Arzoumanian, J. F. Petrignani, M. Pierrot, F. Ridouane and J. Sanchez, Inorg. Chem., 1988, 27, 3377.

11 J. Tachibana, T. Imamura and Y. Sasaki, J. Chem. Soc., Chem. Commun., 1993, 1436; M. Minato, D.-Y. Zhou, K.-i. Sumiura, Y. Oshima, S. Mine, T. Ito, M. Kakeya, K. Hoshino, T. Asaeda, T. Nakada and K. Osakada, Organometallics, 2012, 31, 4941.

12 G. Lyashenko, G. Saischek, A. Pal, R. Herbst-Irmer and N. C. Mösch-Zanetti, Chem. Commun., 2007, 701.

13 C. Y. Lorber, S. P. Smidt and J. A. Osborn, Eur. J. Inorg. Chem., 2000, 655.

14 M. A. Katkar, S. N. Rao and H. D. Juneja, RSC Adv., 2012, 2, 8071; S. N. Rao, N. Kathale, N. N. Rao and K. N. Munshi, Inorg. Chim. Acta, 2007, 360, 4010; W. A. Herrmann, G. M. Lobmaier, T. Priermeier, M. R. Mattner and B. Scharbert, J. Mol. Catal. A: Chem., 1997, 117, 455. 
15 G. Lyashenko, G. Saischek, M. E. Judmaier, M. Volpe, J. Baumgartner, F. Belaj, V. Jancik, R. Herbst-Irmer and N. C. Mösch-Zanetti, Dalton Trans., 2009, 5655.

16 M. E. Judmaier, C. Holzer, M. Volpe and N. C. MöschZanetti, Inorg. Chem., 2012, 51, 9956.

17 T. Arumuganathan, M. Volpe, B. Harum, D. Wurm, F. Belaj and N. C. Mösch-Zanetti, Inorg. Chem., 2012, 51, 150; M. Volpe and N. C. Mösch-Zanetti, Inorg. Chem., 2012, 51, 1440; J. A. Schachner, P. Traar, C. Sala, M. Melcher, B. N. Harum, A. F. Sax, M. Volpe, F. Belaj and N. C. MöschZanetti, Inorg. Chem., 2012, 51, 7642; M. E. Judmaier, C. H. Sala, F. Belaj, M. Volpe and N. C. Mösch-Zanetti, New J. Chem., 2013, 37, 2139; N. C. Mösch-Zanetti, D. Wurm, M. Volpe, G. Lyashenko, B. Harum, F. Belaj and J. Baumgartner, Inorg. Chem., 2010, 49, 8914.

18 S. K. Sharma, P. S. May, M. B. Jones, S. Lense, K. I. Hardcastle and C. E. MacBeth, Chem. Commun., 2011, 47, 1827; W.-D. Wang and J. H. Espenson, Inorg. Chem., 2001, 40, 1323; B. G. Jacobi, D. S. Laitar, L. Pu, M. F. Wargocki, A. G. DiPasquale, K. C. Fortner, S. M. Schuck and S. N. Brown, Inorg. Chem., 2002, 41, 4815.

19 G. Alesso, M. Sanz, M. E. G. Mosquera and T. Cuenca, Eur. J. Inorg. Chem., 2008, 4638.
20 J. Liimatainen, A. Lehtonen and R. Sillanpää, Polyhedron, 2000, 19, 1133.

21 K. Most, J. Hoßbach, D. Vidović, J. Magull and N. C. Mösch-Zanetti, Adv. Synth. Catal., 2005, 347, 463; K. Heinze and A. Fischer, Eur. J. Inorg. Chem., 2007, 1020; K. Hüttinger, C. Förster, T. Bund, D. Hinderberger and K. Heinze, Inorg. Chem., 2012, 51, 4180.

22 B. L. Tran and C. J. Carrano, Inorg. Chem., 2007, 46, 5429; A. J. Millar, C. J. Doonan, P. D. Smith, V. N. Nemykin, P. Basu and C. G. Young, Chemistry, 2005, 11, 3255; V. N. Nemykin and P. Basu, Inorg. Chem., 2005, 44, 7494.

23 W. R. Thiel and T. Priermeier, Angew. Chem., Int. Ed. Engl., 1995, 34, 1737; J.-Y. Piquemal, S. Halut and J.-M. Brégeault, Angew. Chem., Int. Ed., 1998, 37, 1146; M. Herbert, F. Montilla, E. Álvarez and A. Galindo, Dalton Trans., 2012, 41, 6942; M. Bagherzadeh, M. Zare, V. Amani, A. Ellern and L. Keith Woo, Polyhedron, 2013, 53, 223.

24 J. A. Brito, M. Gomez, G. Muller, H. Teruel, J.-C. Clinet, E. Dußach and M. A. Maestro, Eur. J. Inorg. Chem., 2004, 4278.

25 J. Leppin, C. Förster and K. Heinze, Inorg. Chem., 2014, 53, 1039.

26 K. F. Morris and C. S. Johnson, J. Am. Chem. Soc., 1993, 115, 4291. 